\title{
Krzysztof Maliszewski
}

Uniwersytet Śląski

w Katowicach

\section{Introcepcja w filozofii wychowania Bogdana Nawroczyńskiego - zarys potencjału kategorii}

\section{Orientacja wewnętrzna}

W kształceniu i umysłu, i charakteru - jeśli tylko nie jest ono pojmowane powierzchownie jako prosta adaptacja do standardów - stawką jest indywidualna żywotność wartości. Nie chodzi o to, by człowiek zachowywał się w określony sposób z uwagi na sankcje społeczne, lecz by miał wewnętrznie zlokalizowane dyspozycje do działania urzeczywistniającego dobre stany rzeczy. W artykule Zasady moralne $w$ wychowaniu z roku 1909 John Dewey pisał, że trzeba rozróżnić między pojęciami moralnymi, które stały się składnikiem osobowości, a pojęciami o moralności, które choć przywoływane, pozostają bez wpływu na postępowanie. Zadaniem wychowawcy jest troska o to, aby pojęcia - np. uczciwości czy grzeczności - były nabywane w sposób żywotny, by stawały się ideami poruszającymi ${ }^{1}$. Jest to jeden $z$ fundamentalnych toposów pedagogiki kultury. Bogdan Suchodolski czytelnie wyłożył problem w Wychowaniu moralno-społecznym. Traktowanie dóbr kulturalnych jako bezwarunkowo obowiązujących prowadzi nieuchronnie do narastania nieszczerości (rozdźwięku między poczuciem wewnętrznym a deklaracjami) i tym samym de facto podminowuje wartości. One mają przecież działać w duszach, a nie uchodzić za wartości. Z drugiej jednak strony, nie można się ograniczać tylko do zaspokajania aktualnie rozbudzonych potrzeb, bo to skazywałoby nas na powierzchowność. Dlatego: „Droga, która by łączyła żywotność wartości z jej normatywnym charakterem, jest trudną, ale jedynie właściwą drogą wychowania"2. Chodzi zatem o to, by przynajmniej niektóre składniki edukacyjnej oferty zostały uwewnętrznione, aby ich roszczenie do ważności zostało przyjęte i zorientowało działanie, aby uruchamiały myślenie

${ }^{1}$ Por. J. Dewey, Wybór pism pedagogicznych, Wrocław-Warszawa-Kraków 1967, s. 178-179.

${ }^{2}$ B. Suchodolski, Wychowanie moralno-społeczne, [w:] Encyklopedia wychowania, red. S. Łempicki i in., Warszawa 1935, z. 14, s. 892. 
egzystencjalne. Tak wybitny teolog Romano Guardini nazywał refleksję, w której daną sprawę rozpatruje się w przytomności własnego istnienia, poważnie jako coś, co określa zachowanie, a nie jest jedynie zbiorem informacji ${ }^{3}$.

Bogdan Nawroczyński ów moment wewnętrznej aksjocentrycznej orientacji człowieka - przesilenia rozwojowego, w którym z materiału odziedziczonego kulturowo kształtuje się osobista dyspozycja do działania - opisywał za pomocą pożyczonego od Williama Sterna terminu introcepcja. Warto tę kategorię przypomnieć, jako że wskazuje na kluczowy i subtelny, czyli także trudno uchwytny i często zapoznawany, punkt procesu wychowania. Przybliżając pojęcie introcepcji, staram się odsłonić - choć tylko w zarysie - potencjał symboliczny, jaki w nim tkwi. Mimo iż Nawroczyński nie używał niektórych przywoływanych przeze mnie terminów i nie odwoływał się do pewnych kontekstów, to, co pisał o introcepcji, otwiera nas na wiele obszarów i kategorii współczesnej humanistyki. W niniejszym tekście próbuję ilustracyjnie naszkicować kilka dróg interpretacji, aby pokazać, że introcepcja to nie termin muzealny, lecz domagająca się nowych wykładni, poszerzeń i pogłębień, współczesna nader ważka idea.

\section{Introcepcja}

Bogdan Nawroczyński ujmował kulturę dynamicznie - bardziej jako serie czynności niż zbiory obiektów. Pisał:

Aby w pełni zrozumieć, że kultura żywa nie ma charakteru wytworowego, pomyślmy sobie, co by się z nią stało, gdyby tak nagle zahamować w niej wszystkie czynności, pozostawiając tylko wytwory. Byłyby wówczas narzędzia, maszyny - ale nikt by ich nie używał; byłyby dzieła sztuki, ale nikt by się nimi nie rozkoszował; byłyby biblioteki i szkoły, ale nikt by w nich nie studiował; byłyby kościoły, ale nikt by się w nich nie modlił... ${ }^{4}$

Trzy procesy (typy aktywności) decydują o rozwoju kultury: wnikające używanie (rozumienie wytworu kulturalnego - zdolność do uchwycenia jego sensu i posługiwania się nim), ksztaltowanie się (krystalizowanie się struktur wewnętrznych jednostki, którego fundamentem jest introcepcja) oraz twórczość (generowanie dóbr kulturalnych).

W strukturach wewnętrznych człowieka (aksjocentrycznych układach spoistych, takich jak wykształcenie, charakter, typ osobowości etc.) zachodzą zmiany pod wpływem obcowania z dobrami kulturalnymi. Człowiek wrasta duchowo w atmosferę otoczenia, zmienia się pod wpływem wykonywanych zajęć, np. nabywa w zależności od praktykowanej profesji cech charakterystycznych duchownego, artysty, handlowca. Samo wnikanie w dzieła kultury (rozumienie) nie

\footnotetext{
${ }^{3}$ Por. R. Guardini, Bóg daleki, Bóg bliski, Poznań 1991, s. 39-40.

${ }^{4}$ B. Nawroczyński, Życie duchowe. Zarys filozofii kultury, Kraków-Warszawa 1947, s. 134.
} 
oznacza jeszcze, że człowiek się zmienia. Można zachować dystans do wartości, której sens uchwyciliśmy - nie uznać jakiegoś celu za swój, mimo że pojmujemy działania dążących do niego innych ludzi. Czasami zanika jednak rezerwa wobec cudzych dążeń i odczytaną w kulturze wartość jednostka uznaje za własną. Ten proces przyswojenia wartości, przesunięcia z heterotelii (świata celów obcych) do autotelii (świata celów własnych) określał Nawroczyński mianem introcepcji. Ten właśnie moment to podstawa ksztaltowania się wewnętrznego - „najgłębszego z pedagogicznych procesów"s.

W jakich warunkach dochodzi do introcepcji? Jakie okoliczności towarzyszą temu aktowi? Bogdan Nawroczyński zdaje się podpowiadać dwie kluczowe pedagogiczne reguły: nastrojenie na sens i aktywność. Introcepcja nie jest możliwa bez wcześniejszego wnikającego używania, a to z kolei wymaga - słyszymy w tym miejscu echo Georga Kerschensteinera - pokrewieństwa zewnętrznej struktury duchowej (sensu wytworu kulturowego) i wewnętrznej struktury duchowej (nastawienia jednostki na określone wartości). Za Kazimierzem Twardowskim polski pedagog tłumaczył, że dzieło jest tylko częściową przyczyną wzbudzenia w odbiorcy przeżyć. Reszta bodźców tkwi w dyspozycjach użytkownika - w jego kompetencjach (np. znajomości języka) oraz właśnie w pokrewieństwie jego struktur wewnętrznych. Bez nastawienia indywidualności na dany w wytworze sens człowiek - chociażby formalnie rozumiał tekst, dzieło sztuki, funkcjonowanie maszyny, przebieg jakiejś ludzkiej praktyki - naprawdę będzie się „mijał” z niesionym przez ów wytwór znaczeniem, jak kiepski krytyk, który chybia w ocenie mistrza, lecz nie ma o tym pojęcia. Aby coś zrozumieć i przejąć dla siebie, nie wystarczy opanowanie kodu i osadzenie szczegółów w szerszym kontekście, potrzebne jest jeszcze intuicyjne wczucie się w niesione tam wartości. Poszukiwanie sensu wytworu kulturowego, któremu towarzyszy próba nastrojenia wewnętrznego, budowania dyspozycji do odbioru, to podstawowy warunek niwelowania ślepoty na wartości, co prawda pozwalającej wiedzieć o wartości, ale już nie żyć nią.

Druga zasada, którą wskazuje Nawroczyński explicite w kontekście introcepcji, to aktywność. Kontakt z wytworami kultury, jeśli ma doprowadzić do przesunięcia $\mathrm{z}$ heterotelii do autotelii, nie może być jedynie pasywną stycznością:

Obcowanie przy tym powinno mieć charakter a $\mathrm{k} \mathrm{t} \mathrm{y} \mathrm{w} \mathrm{n} \mathrm{y.} \mathrm{Bierne} \mathrm{tylko} \mathrm{poddawanie} \mathrm{się} \mathrm{ich}$ wpływowi nie wystarcza, choćby trwało przez dłuższy okres [...]. Ktoś może latami całymi przebywać w pierwszorzędnej galerii obrazów - powiedzmy w charakterze ajenta policji - i tylko się w niej nudzić. Ktoś inny po znacznie krótszym pobycie może z niej wyjść innym człowiekiem, o ile się przygotował do oglądania zgromadzonych tam arcydzieł sztuki przez odpowiednie studia, o ile walczył z trudnościami, zagradzającymi drogę do ich zrozumienia, o ile nie szczędził wysiłków, aby wniknąć w ich sens, o ile się z tym sensem mocował, jak z jakimś potężnym aniołem czy szatanem ${ }^{6}$.

\footnotetext{
${ }^{5}$ Tamże, s. 145.

${ }^{6}$ Tamże, s. $144-145$.
} 
Oto klucz do introcepcji, jaki nam polski pedagog pozostawił: walka z przeszkodami rozumienia, mocowanie się z sensem.

Tak pojmowana introcepcja odsyła nas do kilku ważnych rejonów współczesnej humanistyki, z których pedagogika może czerpać, aby pogłębić rozumienie wychowawczo kluczowego procesu podmiotowej absorpcji kultury. Oto wybrane przykłady i - rzecz jasna - tylko jedna z wielu możliwości konceptualizacji tej kwestii.

\section{Zwrot ku wnętrzu}

Momentem aksjologicznym ${ }^{7}$ - tym, co odróżnia wartość od innych bytów jest nieobojętność dla podmiotu - ich poruszająca moc, ich ważność. Charles Taylor opisał modernistyczny zwrot ku wnętrzu, w ramach którego - po rozpadzie uniwersalnego ideowego horyzontu - wartościowość zapośredniczona jest w przeżyciu osobistym ${ }^{8}$. Kanadyjski filozof posłużył się przykładem sztuki wieku XX, która odkrywa i celebruje to, co subiektywne - tajniki uczuć, strumień świadomości etc. Jednocześnie jednak następuje decentracja podmiotu - zainteresowanie koncentruje się nie na autoekspresji zintegrowanego ja, które obwieszcza głęboką prawdę o sobie i świecie, lecz na języku i na przeobrażeniu artystycznym. Od epoki romantyzmu schronieniem przed zmechanizowanym, wypranym z wartości światem staje się ludzkie wnętrze - myśl, świat przeżywany, doświadczenie - to, co w człowieku nie przystaje do wszechogarniającego technicyzmu i instrumentalizmu. Aliści tęskniąc za autentyczniejszym życiem, za głębszym i mocniejszym źródłem moralności moderniści wieku XX nie mogli - tak jak romantycy - szukać pocieszenia w samym uczuciu, ani w pewności, że rzeczywistość jest emanacją ducha. Nie akceptowali już założeń o harmonii podmiotu i świata, o dobroci wewnętrznej i zewnętrznej natury. Dlatego zwrot ku wnętrzu, ku własnym przeżyciom nie oznacza orientacji na prostą artykulację subiektywności, ale raczej na fragmentaryczne, językowo zapośredniczone doświadczenie problematyzujące tożsamość. Decentracja stanowi uzupełnienie introwersji.

To, co jest istotą introcepcji opisywanej przez Nawroczyńskiego (przesunięcie ku temu, co wlasne), okazuje się w perspektywie rozważań Taylora fundamentalnym rysem kultury współczesnej. Ale jest i różnica. Wizja podmiotowości, jaka wyłania się z modernistycznej twórczości artystycznej, jest rozproszona i językowo zapośredniczona, i nie ma już - jak w dziele Nawroczyńskiego - jednoznacznego statusu aksjocentrycznego układu spoistego. Niekoniecznie jest tak, jak uważał polski pedagog, że im głębsze przeżycie sensu towarzyszy jednostce,

\footnotetext{
${ }^{7}$ Por. A. Niemczuk, Stosunek wartości do bytu. Dociekania metafizyczne, Lublin 2005, s. 182.

${ }^{8}$ Por. C. Taylor, Źródła podmiotowości. Narodziny tożsamości nowoczesnej, Warszawa 2001, s. 837-909.
} 
tym bardziej pozytywnie zintegrowana jest jej osobowość, tym bardziej harmonijny jej świat wewnętrzny. Niekoniecznie też fragmentaryzacja doświadczenia jest zjawiskiem negatywnym. Bywa tak, że właśnie mocne ukierunkowanie na cel, poważne wniknięcie w jakąś wartość ujawnia dopiero niespodzianki, pułapki, ambiwalencje czy wielowymiarowość, ukryte w strukturze danego dobra oraz we własnym ja, odbierając - zbawiennie nieraz - poczucie pewności i spójności. W każdym razie warto z użyciem kategorii zwichnięcia (out of joint) reinterpretować teorię introcepcji. Jestem przekonany, że owocne będzie również wbudowanie w nią toposu przeżycia osobistego. Pisał Taylor:

ukierunkowanie na wnętrze stanowi element wrażliwości modernistycznej w równym stopniu co romantycznej. A to, co wewnętrzne, jest głębokie: to, co bezczasowe, mityczne i archetypowe [...]może mieć charakter międzyosobowy. Ale dostęp do niego możemy uzyskać jedynie poprzez to, co osobowe. W tym sensie głębia pozostała dla nas czymś wewnętrznym [...]. Być może wynosi nas ona poza to, co podmiotowe, ale droga do niej w sposób nieuchronny wiedzie poprzez podwyższoną świadomość przeżycia osobistego ${ }^{9}$.

Otwieranie dziedzin kultury i zawartych w nich źródeł moralnych - tłumaczył Taylor - nie może się już dziś odnosić do solidnego, powszechnie akceptowanego tła i stanowi wyraz osobistych wizji, jednostkowych doświadczeń - ale takich, w których inni mogą współuczestniczyć. Twórcy - jak Eliot, Pound, Proust, Joyce, Mann - oferują odbiorcom coś, co uważają za dostępne dla wszystkich, niemniej jednak „,W postaci prześwietlonej własną wrażliwością" ${ }^{10}$. Podpowiadane przez kanadyjskiego myśliciela tropy poszukiwania sensu w trybie osobistego rezonansu, strategii otwierania kultury przez prześwietlanie własną wrażliwością to kapitalne wątki pedagogiczne, którymi wzbogacić trzeba motyw aktywności w teorii introcepcji Nawroczyńskiego.

\section{Pragnienie}

Jeśli myślimy o procesie przyjmowania wartości i celów za własne, to uwaga kieruje się nieuchronnie ku kwestii pożądania. Trzeba pragnąć i chcieć danego dobra, aby wyprowadzić je $\mathrm{z}$ heterotelii w strefę autotelii. $\mathrm{O}$ ten wątek uzupełnił teorię introcepcji Zygmunt Mysłakowski. Dwie z trzech zasad introcepcji, jakie sformułował, dotyczyły właśnie pożądania. Aby jakaś norma mogła stać się motywem postępowania, wejść w strukturę personalną jako element trwały i osobisty, jednostka musi odczuwać zapotrzebowanie, czyli być w zakresie danego dobra uwrażliwiona (zmuszenie, ugięcie wychowanka nigdy nie da efektu wewnętrznego przyzwolenia). Poza tym najłatwiej introcepcja dokonuje się wtedy, gdy

\footnotetext{
${ }^{9}$ Tamże, s. 888 .

10 Tamże, s. 908.
} 
człowiek z celami czy wartościami może łączyć energię emocjonalną (libido) - w edukacji potrzebny jest zatem umożliwiający przeżywanie Eros pedagogiczny, a nie suche, prawnicze, rzeczowe wymagania ${ }^{11}$. Jeśli wychowanie polega na dialogu - od formalnego dydaktycznego po Bachtinowski dialog z niewspółobecnym - nie wolno zapominać o zaleceniu Jurija Łotmana: ,sytuacja wzajemnego pociągu do kontaktu powinna poprzedzać sam kontakt"12. Wychowawczy problem budowania pociągu do kontaktu i zapotrzebowania na wartości odsyła nas do przynajmniej trzech interesujących kontekstów: psychoanalitycznego, antropologicznego i etycznego.

Po pierwsze, w perspektywie Lacanowskiej psychoanalizy pragnienie zakorzenione jest $\mathrm{w}$ braku. Pragnienie nie ma charakteru świadomego (nie można go utożsamić ze zwykłym wolicjonalnym „chceniem”) - wyzwala ono nie tyle pytanie: na co mam ochotę?, ile raczej dociekania w niejasnych kwestiach: o co mi chodzi? co mnie gryzie? kim jestem dla innych? ${ }^{13}$ Jak pisała Hanna Stępniewska-Gębik:

Efektem takiego pytania staje się próba obnażenia miejsca w dyskursie, w którym dzieje się coś istotnego z punktu widzenia kondycji jednostki, jej koncepcji siebie, jak i jej kompetencji do działania i do radzenia sobie z samą sobą ${ }^{14}$.

Takie ujęcie pragnienia generuje kilka ważnych dla pedagogiki pytań, np.: jakie warunki muszą być spełnione, aby nauczyciele byli w stanie obudzić w uczniu poczucie braku, który ten chciałby zapełnić? ${ }^{15} \mathrm{~W}$ jaki sposób inspirować wychowawców do zajmowania postawy „strażników braku”, wspierających troskę o rozpoznawanie deficytów, pułapek i zagrożeń posiadanego potencjału, pobudzających poczucie „zaległości kulturowej”? ${ }^{16}$ Czy oferta edukacyjna (np. literatura) jest w szkole, na uczelni obecna na tyle przenikliwie, aby pomagać w rozpoznawaniu własnych pragnień? Na ile humaniści (w tym pedagodzy i nauczyciele przedmiotów humanistycznych) potrafią - wbrew scjentystycznym wymogom dążenia do jednoznaczności - operować metaforami, w których - wedle Lacana - słyszalny jest sens pragnienia, niedostępny w powszednich konwencjach językowych?

${ }^{11}$ Por. Z. Mysłakowski, Wychowanie człowieka w zmiennej społeczności. Studia z filozofii wychowania, Warszawa 1965, s. 180-183.

${ }^{12}$ J. Łotman, Uniwersum umystu. Semiotyczna teoria kultury, Gdańsk 2008, s. 228.

${ }^{13}$ Por. S. Žižek, Lacan. Przewodnik Krytyki Politycznej, Warszawa 2008, s. 55-76.

${ }^{14} \mathrm{H}$. Stępniewska-Gębik, Pedagogika i psychoanaliza. Potrzeba-pragnienie-inny. Konteksty epistemologiczne dla pedagogiki w świetle psychoanalitycznej koncepcji Jacques'a Lacana, Kraków 2004, s. 85.

${ }^{15}$ Por. K. Węc, Psychoanaliza $w$ dyskursie edukacyjnym. Radykalność humanistyczna teorii i praktyki pedagogicznej. Konteksty nie tylko Lacanowskie, Toruń 2007, s. 414.

${ }^{16}$ Por. L. Witkowski, Wyzwania autorytetu w praktyce spotecznej $i$ kulturze symbolicznej (przechadzki krytyczne w poszukiwaniu dyskursu dla teorii), Kraków 2009, s. 22. 
Po drugie, przenoszenie pragnienia to jedno z elementarnych zjawisk antropologicznych. Rene Girard rozwinął teorię pragnienia mimetycznego, które powstaje z naśladowania cudzego pragnienia.

Ochota na jedzenie czy na seks nie jest jeszcze pragnieniem. Jest to popęd biologiczny, który pragnieniem staje się dzięki naśladowaniu jakiegoś wzorca [...]. Skoro pragnienie ma charakter mimetyczny, a zatem naśladowczy, to podmiot pragnie przedmiotu, który posiada lub którego pragnie jego wzorzec ${ }^{17}$.

Jeśli podmiot i jego model przebywają w różnych środowiskach (pośrednictwo zewnętrzne), następuje bezkonfliktowy przekaz dążeń kulturowych. Jednak gdy podmiot i wzór funkcjonują w tej samej płaszczyźnie społecznej, są „sąsiadami” (pośrednictwo wewnętrzne) - pojawia się rywalizacja mimetyczna. Powstaje „relacja sobowtórów” - wyniszczające wzajemne naśladownictwo, w ramach którego znika sam przedmiot pragnienia, obecny już tylko jako pretekst służący do pokonania rywala. Girard pokazał, że u podłoża przekazu kulturowego leży mechanizm mimetyczny, ale także to, iż bez odpowiedniego dystansu prowadzi on do nakręcania spirali walki. Edukacja nie funkcjonuje bez wzorców - pragnienia są społecznie przenoszone, atoli nazbyt symetryczne partnerstwo (zniszczenie pośrednictwa zewnętrznego) albo pojmowanie wychowania stricte jako uruchamiania imitacji prowadzą często do erupcji kryzysów mimetycznych, w ogniu których zapomnieniu, unieważnieniu ulega sam obiekt pragnienia - rzecz jasna, nie mogąc tym samym stać się składnikiem autotelii.

Po trzecie, rozbudzanie pragnień jest istotą tego, co Henri Bergson nazwał moralnością otwartą. Wielkie duchy ludzkości (mędrcy, święci, prorocy) torują drogę moralności uniwersalnej, ale nie działają przez nacisk, nie rozkazują, tylko apelują, wzbudzają oddźwięk i tym samym udowadniają, że jest w nas potencjalna energia do wykroczenia poza mentalność plemienną ${ }^{18}$. Powinność naturalna (społeczna) jest presją, natomiast powinność w moralności pełnej to wezwanie, wzbudzone pragnienie. Pisał Bergson:

Podczas słuchania muzyki wydaje się nam, że nie bylibyśmy w stanie chcieć czegoś innego niż to, co sugeruje nam muzyka, i że działalibyśmy zgodnie z tym, w sposób naturalny i konieczny, gdybyśmy nie odpoczywali właśnie od działania, słuchając muzyki. Niech muzyka wyraża radość, smutek, litość, sympatię - w każdym momencie jesteśmy tym, co ona wyraża. [...] Prawdę mówiąc, nie wprowadza ona tych uczuć w nas; raczej nas wprowadza w te uczucia, jak przechodniów, których nakłaniałoby się do tańca. W ten sposób postępują nauczyciele moralności. Życie jest dla nich pełne odgłosów niespodziewanych uczuć, jakie mogłyby stworzyć nową harmonię; pozwalają nam wchodzić wraz ze sobą w tę muzykę, byśmy mogli przemieniać ją w działanie ${ }^{19}$.

\footnotetext{
${ }^{17}$ R. Girard, Początki kultury, Kraków 2006, s. 62.

${ }^{18}$ Por. L. Kołakowski, Bergson, Warszawa 1997, s. 100.

${ }^{19}$ H. Bergson, Dwa źródta moralności i religii, Kraków 1993, s. 45-46.
} 
Dobry pedagog działa jak muzyka - generuje pewien świat „dźwięków” (głosów, znaczeń, tonów aksjologicznych) i zaprasza do podjęcia go. Znowu pojawia się istotne pedagogiczne pytanie: Jakie warunki muszą być spełnione, jakie dyspozycje ukształtowane, żeby sama obecność wychowawcy - bez metodyki nacisku - okazała się dla podopiecznych znacząca, zdolna rozbudzić pragnienie?

\section{Mit}

Kolejnym ważnym kontekstem, do którego odsyła teoria introcepcji, jest sfera mitu - nie w potocznym znaczeniu ułudy, lecz w Eliadowskiej optyce opowieści aksjonośnej. Jeśli bowiem introcepcja polega na tym, że cudza wartość - o której mamy wiedzę i którą nawet dobrze rozumiemy - staje się naszą wartością, czyli głębokim personalnym motorem działania, kluczowego znaczenia nabiera teza Leszka Kołakowskiego o skutecznej transmisji tego, co ma sens i co jest cenne, wyłącznie w formie mitycznej. Efektywne dziedziczenie wartości jest zawsze dziełem autorytetu:

Ale wartości dziedziczone pod zniewalającym działaniem autorytetu, dziedziczone są w swojej mitycznej formie, tj. nie są dziedziczone jako informacje o faktach socjalnych lub psychicznych („,to lub owo uchodzi za wartość"), lecz właśnie jako informacje o tym, co jest lub nie jest wartością. [...] Mity, które uczą nas, że coś jest wartością po prostu, są nie do uniknięcia, jeśli społeczeństwo ludzkie ma istnieć ${ }^{20}$.

Rzeczywiście wydaje się, że niezbywalne dla procesu introcepcji jest roszczenie do prawdziwości. Nie można głęboko uwewnętrznić wartości czy punktu widzenia tylko na podstawie arbitralnej decyzji, bez wiary w samą ich ważność. Bernard Williams thumaczył, że nie możemy przyswoić sobie żadnych przekonań li tylko z własnej woli. Gdyby to było możliwe, musielibyśmy asymilować je niezależnie od tego, czy są prawdziwe, czy fałszywe. Nie sposób obrać takiej strategii, ponieważ wyklucza ona traktowanie owych przekonań jako własnych. Przekonanie nie jest tożsame z publicznym uznawaniem czegoś (można przecież wygłaszać nieszczere opinie). Przekonanie dąży do prawdziwości ${ }^{21}$. Inna sprawa, że jest różnica między świadomością prawdy horyzontu a roszczeniem do absolutnej pozycji poznawczej (view from nowhere).

Osadzenie procesu introcepcji w przestrzeni mitycznej nie oznacza niewolniczego uzależnienia od autorytetu i tradycji. Introcepcja nie jest prostym kopiowaniem cudzych celów, bo wtedy nie dochodziłoby do budowy rzeczywistej autotelii - podmiot byłby jedynie kolonizowany obcym materiałem, omotywany włóknami fałszywej świadomości, przypominając bardziej Golema niż osobę.

\footnotetext{
${ }^{20}$ L. Kołakowski, Obecność mitu, Wrocław 1994, s. 32.

${ }^{21}$ Por. B. Williams, Ile wolności powinna mieć wola? Warszawa 1999, s. 6-22.
} 
Tradycja jawi się nie tyle jako spójna scheda, ile raczej jako nieustający spór rozmaitych wersji. Efektywne dziedziczenie, o którym pisał Kołakowski, to nie powtórzenie nie zmieniające niczego, lecz - zgodnie z tradycją Heglowską - zachowanie przekształcające. Kto przyjmuje jakąś wartość za własną, dziedziczy bardziej ruch, zadanie do wykonania, niż rezultat do osiągnięcia. Na tym polega opisywana przez Lecha Witkowskiego „socjalizacja krytyczna”:

Postulaty socjalizacji „krytycznej” tymczasem zorientowane są na osiągnięcie takiego poziomu kompetencji działania, na którym wejście w konflikt z zastanymi konwencjami czy definicjami sytuacji i podjęcie działań zmierzających do przedłożenia im alternatywy jest normalnym sposobem reagowania na świat ${ }^{22}$.

Introcepcja, jako uznawanie cudzych wartości za swoje, nie może być pojmowana poza oddziaływaniem autorytetu, lecz nie wyklucza wcale wchodzenia z nim w spór i niezgodę, podobnie jak nie wyklucza usuwania tego, co własne. Bogdan Nawroczyński, pisał, że duchowa struktura wewnętrzna może się rozrastać (np. jak w przypadku osobowości Goethego) lub przebudowywać, nieraz radykalnie (jak w przypadku Szawła z Tarsu). Introcepcja zachodzi nawet w strukturach opornych, bo przeszkody bywają przezwyciężane stopniowo. Nieświadomie organizuje się w człowieku nowa struktura, która ujawnia się któregoś dnia - zwykle po jakimś wstrzą́nieniu ${ }^{23}$ - i zastępuje starą ${ }^{24}$. Ten wątek teorii polskiego pedagoga warto uzupełnić o motyw aktywnej rezerwy do własnych celów i zaangażowann ${ }^{25}$.

\section{Zakończenie}

Bogdan Nawroczyński opisał ważki pedagogiczny proces, w ramach którego z puli wartości kulturowych - dzięki emocjonalnemu nastawieniu na sens oraz aktywnemu mocowaniu się z tym sensem - jednostka wybiera niektóre i uznaje

${ }^{22}$ L. Witkowski, Tożsamość i zmiana. Wstęp do epistemologicznej analizy kontekstów edukacyjnych, Torun 1988, s. 212.

${ }^{23}$ Stefan Kunowski wspominał, że w sztuce wychowania chodzi o wywołanie „wstrząsów introcepcyjnych” oraz że niebezpieczny dla introcepcji jest „moment zastoju” - niezmienność metod, automatyzacja czynności - powodujący więdnięcie wartości albo ich nieadekwatną recepcję. Por. S. Kunowski, Wartości w procesie wychowania, Kraków 2003, s. 117-121.

${ }^{24}$ Por. B. Nawroczyński, Życie duchowe..., s. 146.

${ }^{25}$ Gregory Bateson pisał o tertiary learning - uczeniu się uwalniania od nawyków, zapobiegania przyzwyczajeniu, przekuwania fragmentarycznego doświadczenia w nowe - ale tylko czasowe - wzorce. Por. Z. Bauman, Edukacja: wobec, wbrew i na rzecz ponowoczesności, [w:] Wychowanie, t. 1, Pojęcia - procesy - konteksty, red. M. Dudzikowa, M. Czerepaniak-Walczak, Gdańsk 2007, s. 139-141. Z kolei Aleksander Nalaskowski mówił o eksternalizacji jako procesie socjalizacyjnego odtrucia - wyrzucania z podmiotowości tego, co wcześniej uznane zostało za własne. Por. A. Nalaskowski, Dzikość i zdziczenie jako kontekst edukacji, Kraków 2006, s. 61. 
za własne, tym samym poszerzając i uspójniając (lub w ukryciu przebudowując) podmiotowe struktury wewnętrzne. Starałem się pokazać, że jest to koncepcja, którą warto przywoływać nie tylko jako historyczne dokonanie klasyka pedagogiki, ale przede wszystkim jako deskrypcję kluczowego momentu niepowierzchownie pojmowanej edukacji, w dodatku koncepcję podatną na rozwój w nowych obszarach teoretycznych. Introcepcja może być czytana w kontekście modernistycznego zwrotu ku wnętrzu z wykorzystaniem kategorii przeżycia osobistego i prześwietlenia wrażliwością. Może być również interpretowana przez pryzmat pragnienia, co odsyła myślenie pedagogiczne nie tylko $\mathrm{w}$ rejon Erosa pedagogicznego (zaangażowania, energii, miłości) i dydaktyki przeżycia, ale także wprowadza to myślenie w pole braku, zaległości kulturowej, troski jakby powiedział Heidegger - o wlaściwą biedę; również w pole jakości kontaktu edukacyjnego, którego stawką nie może być ocena czy realizacja programu, lecz zysk symboliczny uczestników (co zależy $\mathrm{m}$. in. od kompetencji metaforyzacji nauczania, od styczności z ,wielkimi duchami” i znaczącymi tekstami oraz od dyspozycji nauczycieli i wychowawców do komponowania z głosów, znaczeń i wartości życionośnych ofert); wreszcie w pole mimesis i uczulenia na groźbę wybuchu rywalizacji mimetycznej niszczącej wartości, które miały stać się własne. Introcepcja może zostać także osadzona w przestrzeni mitu, ujawniając, że najprawdopodobniej efektywne dziedziczenie wartości wymaga $\mathrm{z}$ jednej strony rozbudzania wyobraźni mitycznej, z drugiej zaś - inicjowania krytycznej socjalizacji.

Ujmując rzecz szkicowo i lapidarnie: introcepcja to wydarzenie edukacyjne, w którym za sprawą prześwietlonego wrażliwością przekazu kulturowego budzi się w jednostce poczucie wlaściwej biedy, prowadząc do mocowania się z sensem i wewnętrznej akceptacji najlepszej aktualnie wyszukanej wersji tradycji. 